\title{
Post-traumatic tricuspid insufficiency: a case report
}

\author{
Travma sonrası triküspit yetersizliği: Bir olgu sunumu
}

\author{
Ufuk TÜTÜN, Ayşen AKSÖYEK, Ali İhsan PARLAR, Adnan ÇOBANOĞLU
}

\begin{abstract}
Post-traumatic tricuspid insufficiency is a rare complication of chest trauma. An 18-year-old male patient was injured in a bicycle accident from his abdominal and anterior chest wall. The tear on the inferior diaphragmatic surface of the heart was repaired with primary sutures by the attending surgeon. Eighteen years later, he was admitted to the hospital with severe tricuspid regurgitation $(3+/ 4+)$. During the operation, the valve was determined unsuitable for repair and was replaced with a bioprosthesis. The hemodynamic aberrations relevant to an isolated tricuspid valve injury are very often well-tolerated. Reconstructive surgery may be possible in the early period. In the late cases, repair is sometimes not feasible due to degeneration of the valvular apparatus. Replacement with a biological prosthesis may give the best long-term results in longstanding cases.
\end{abstract}

Key Words: Trauma; tricuspid valve insufficiency.
Travma sonrası triküspit yetersizliği göğüs travmasının nadir bir komplikasyonudur. On sekiz yaşında erkek hastanın bisiklet kazasında karın ve göğüs duvarının ön kısmı yaralanıyor. Kalbin inferior diyafragmatik yüzeyindeki yırtık tedavisini yapan doktor tarafından primer dikişle onarılıyor. On sekiz yıl sonra, ciddi triküspit yetersizliği $(3+/ 4+)$ ile hastaneye başvurdu. Operasyonda, kapak onarıma uygun değildi ve biyoprotez kapak ile değiştirildi. İzole triküspit kapak hasarıyla ilgili hemodinamik bozulma sıklıkla iyi tolere edilir. Rekonstrüktif cerrahi erken periyotta mümkün olabilir. Gecikmiş olgularda, onarım valvüler yapıların dejenerasyonuna bağlı bazı durumlarda uygun olmayabilir. Biyolojik protezler ile replasman uzun süreli olgularda uzun dönemde en iyi sonucu verebilir.

Anahtar Sözcükler: Travma; triküspit kapak yetersizliği.
Post-traumatic tricuspid insufficiency is a rare complication of chest trauma. Todd et al. ${ }^{[1]}$ reported the first case regarding traumatic tricuspid insufficiency in 1848. However, it has been reported with increasing frequency during the last 45 years. Over 100 cases have been reported thus far in the literature. Along with the advent of high- speed transportation, the frequency of cardiac injuries, including those of the tricuspid valve, has been rising. Traffic accidents are the leading causes of traumatic tricuspid valve regurgitation, but other unusual mishaps have also been incriminated..$^{[2-5]}$ The great majority of patients were subjects of closed chest trauma. Recently, post-traumatic tricuspid insufficiency has been reported with the deployment of airbags. ${ }^{[6]}$

The hemodynamic alterations related to tricuspid injuries are not dramatic in nature. The hemodynamic aberrations relevant to an isolated tricuspid valve injury are very often well-tolerated.

In this article, we present a case of post-traumatic tricuspid valve injury that was successfully managed with valve replacement.

\section{CASE REPORT}

An 18-year-old male, apparently in perfect health, was involved in an accident while riding a bicycle. He had extensive multiple injures to the face, thoracic cage and abdomen. His abdominal and anterior chest areas were injured by the handlebar of his bicycle. He was transported to a nearby local hospital, and after preliminary resuscitative measures, underwent an emergency laparotomy for the penetrating abdominal 



Fig. 1. (a) One of the major anterior chordae detached from its papillary muscle head. (b) The arrow shows a fibrotic and scarred myocardial tissue on the anterior endocardial wall of the right ventricle under the anterior leaflet of the tricuspid valve. (c) The valve was replaced with a bioprosthesis. (d) The heart was reduced in size on the postoperative chest X-ray taken two months later (left corner: preoperative, right corner: postoperative). and thoracic injuries. A tear on the inferior diaphragmatic surface of the heart was repaired with primary sutures by the attending surgeon.

Eighteen years later, he was admitted to our institution with nausea and palpitation. On physical examination, marked pulsations were observed in the distended veins of the neck. The right ventricular pulsation was palpable along the left sternal border. On auscultation, a holosystolic murmur and early diastolic rumble were audible at the left parasternal area. There was also mild pulsatile hepatomegaly and peripheral edema.

X-ray evaluation of the chest revealed an increase in the cardiothoracic ratio. A transthoracic echocardiography (TTE) demonstrated diastolic fluttering and wide diastolic excursion of the anterior leaflet of the tricuspid valve. The TTE revealed severe tricuspid regurgitation $(3+/ 4+)$, with well-preserved systolic function of the right ventricle. Both the aortic and mitral valves were noted to be completely competent. A TTE study to investigate Ebstein's malformation was unsuccessful.

During the operation, the tricuspid valve annulus was found to be dilated, with the chordae attached to the anterior and posterior leaflets avulsed from their papillary muscles. Must of the free edges of the leaflets were hanging freely and prolapsing into the right atrium. A portion of the anterior leaflet had been pulled in with contraction of the area towards a fibrotic zone in the anterior right ventricular wall. One of the major anterior chordae had detached from its papillary muscle head (Fig. 1a). There was a fibrotic scarred myocardial tissue $\left(1 \times 1 \mathrm{~cm}^{2}\right)$ on the anterior endocardial wall of the right ventricle under the anterior leaflet of the tricuspid valve that probably initially caused increasing regurgitation due to contraction of the leaflet (Fig. 1b). The valve was replaced with a $31 \mathrm{~mm}$ bioprosthesis (Fig. 1c). The postoperative course was uneventful. Postoperatively, the patient improved significantly. He was discharged on the postoperative 6th day on digitalis and diuretics. During the follow-up in the outpatient clinic, the patient had normal physical findings, and the heart had decreased in size on chest X-ray two months later (Fig. 1d).

\section{DISCUSSION}

Tricuspid regurgitation is a rare complication of blunt or penetrating chest trauma. The true incidence of tricuspid valve injury is hard to estimate. Parmley et al. ${ }^{[7]}$ reported that they had determined eight cases of tricuspid valve injury in necropsy specimens of 546 cardiac injuries.

Traumatic tricuspid rupture involves a sudden increase of the right ventricular intracavitary pressure 
during the isometric systolic phase, when the valve is closed.$^{[8]}$ The frequency of this disease is probably underestimated because isolated chronic tricuspid regurgitation is usually well-tolerated. Most patients experience few or no symptoms after the trauma. ${ }^{[9]}$ In general, acute insufficiency of the tricuspid valve following trauma is subtle and insidious. Because of its subclinical course, progressive dilatation of the tricuspid annulus occurs, and the right ventricular dilatation and dysfunction eventually develop before surgery. Finally, annular dilatation, secondary to the right ventricular enlargement, usually intervenes and contributes to the worsening of the regurgitation. There is an interaction between the right ventricular end diastolic volume and the left ventricular function in conditions of right ventricular volume overload. There is an elevation in the left ventricular end diastolic pressure, which in turn may lead to left ventricular functional impairment, and this has been thought to be due to a change in the left ventricular geometry secondary to a leftward displacement of the stiff interventricular septum. As the right-sided pressures rise during the course of the disease process, the foramen ovale may re-open with resultant right-to-left shunting and finally irreversible myocardial damage. ${ }^{[10]}$

Two major concerns have been raised with regard to the traditional management: the timing of the operation and the surgical procedure. ${ }^{[1]}$ The proper timing of surgery has remained controversial. Of course, surgery before serious myocardial damage carries a lower risk. An early operation allows preservation of myocardial reserve by preventing the secondary myocardial changes. An early operation facilitates faster regression of the myocardial changes, if present. Some authors believe that early surgery yields better life quality and expectancy. ${ }^{[10-12]}$

With favorable surgical anatomy, reconstruction of the tricuspid valve is the preferred treatment. If reconstruction is not feasible, valve replacement may be considered. A bioprosthesis is usually preferred on the right side.

Alfieri et al. ${ }^{[13]}$ described that the operative technique is dictated primarily by the specific anatomical lesions encountered at the time of surgery. Early operation facilitates repair of the valve. Repair of the tricuspid valve has been more frequent in recent years. In our case, the extensive annular dilatation and very extensive changes in the leaflets and chordae made repair impossible, with an expectation of good longterm results. The most frequently reported injury is chordal rupture (55\% of the cases), followed by rupture of the anterior papillary muscle $(27 \%)$ and tear of the leaflets $(15 \%) \cdot{ }^{[14]}$ Some surgeons prefer reconstructive surgery. Implantation of artificial chordae, quadrangular resection of the flail segment, chordal transposition, and papillary muscle reimplantation have been suggested in the presence of chordal rupture or papillary muscle rupture, allowing a successful repair in about $45 \%$ of the cases. Significant residual regurgitation after surgery was not unusual. Allfieri et al. ${ }^{[10]}$ adopted a new surgical approach that consists of stitching together the middle point of the free edges of the tricuspid leaflets, producing a clover-shaped valve (Clover technique).

Surgery continues to be the most recommended curative modality. Clinically overt heart failure has been the traditional indication for surgery, which usually consists of tricuspid valve replacement. ${ }^{[1]}$ Delayed repair can result in excessive fibrosis and shortening or elongation of the chordae and damages the leaflets beyond repair, necessitating replacement of the valve. If the pathology of the tricuspid valve is not favorable for reconstructive surgery, replacement with a bioprosthesis is usually undertaken. As in this patient, it should be kept in mind that the degenerative process may be less pronounced on the right side of the heart with respect to the left due to the hemodynamic properties of the right side of the heart.

As a result, reconstructive surgical therapy may be appropriate in post-traumatic tricuspid insufficiencies if early surgical intervention can be undertaken. As irreversible cardiac pathologies like chordal changes, fibrosis and leaflet degeneration develop during the course of the disease process in the late period, we think that valve replacement with a biological prosthesis may give the best long-term results in longstanding cases.

\section{REFERENCES}

1. Todd RB. A case of rupture of the chordae tendineae of the tricuspid valve of the heart with remarks. Duplin Quart J Med Sci 1848;5:1-11.

2. Hirata K, Kyushima M, Asato H, Mototake H, Ie T, Henzan E, et al. Tricuspid regurgitation due to blunt chest trauma. Report of a case and review of the literature. Jpn Heart J 1993;34:361-75.

3. Mary DA, Day JB, Pakrashi BC, Ionescu MI. Isolated tricuspid incompetence after penetrating trauma. Am J Cardiol 1973;31:792-5.

4. Pate JW, Richardson RL Jr. Penetrating wounds of cardiac valves. JAMA 1969;207:309-11.

5. Gerry JL Jr, Bulkley BH, Hutchins GM. Rupture of the papillary muscle of the tricuspid valve. A complication of cardiopulmonary resuscitation and a rare cause of tricuspid insufficiency. Am J Cardiol 1977;40:825-8.

6. Sharma OP, Mousset XR. Review of tricuspid valve injury after airbag deployment: presentation of a case and discussion of mechanism of injury. J Trauma 2000;48:152-6.

7. Parmley LF, Manion WC, Mattingly TW. Nonpenetrating traumatic injury of the heart. Circulation 1958;18:371-96.

8. Naja I, Pomar JL, Barriuso C, Mestres C, Mulet J. Traumatic tricuspid regurgitation. J Cardiovasc Surg (Torino) 1992;33:256-8.

9. Cahill NS, Beller BM, Linhart JW, Early RG. Isolated trau- 
matic tricuspid regurgitation: prolonged survival without operative intervention. Chest 1972;61:689-91.

10. Shahidnoorai S, Ameli M. Post traumatic tricuspid insufficiency: when to intervene? J Cardiovasc Surg (Torino) 1991;32:585-8.

11. van Son JA, Danielson GK, Schaff HV, Miller FA Jr. Traumatic tricuspid valve insufficiency. Experience in thirteen patients. J Thorac Cardiovasc Surg 1994;108:893-8.

12. Fracasso A, Pothen P, Gallucci V. Tricuspid regurgitation caused by blunt chest trauma in association with pericar- dial agenesis: surgical correction after eight years. Thorax 1982;37:75-6.

13. Dounis G, Matsakas E, Poularas J, Papakonstantinou K, Kalogeromitros A, Karabinis A. Traumatic tricuspid insufficiency: a case report with a review of the literature. Eur J Emerg Med 2002;9:258-61.

14. Alfieri O, De Bonis M, Lapenna E, Agricola E, Quarti A, Maisano F. The "clover technique" as a novel approach for correction of post-traumatic tricuspid regurgitation. J Thorac Cardiovasc Surg 2003;126:75-9. 